\title{
Hybrid Mobile Executive Information (m-EIS) System Using Quasar Framework for Indonesia Financial Service Authority
}

\author{
Dina Fitria Murad ${ }^{1 *}$, Wirianto Widjaya ${ }^{2)}$, Dwi Rahmania Noviani ${ }^{3)}$, Nur Fitriyyah ${ }^{4)}$, Liany \\ Minarni Saputri ${ }^{5)}$ \\ 1)2)34)5) Information Systems Department, BINUS Online Learning, Bina Nusantara University, Indonesia \\ Jl. K. H. Syahdan No. 9 Jakarta Barat 11480, Indonesia \\ 1) dmurad@binus.edu, ${ }^{2)}$ wirianto.widjaya@binus.ac.id, ${ }^{3)}$ dwi.noviani@binus.ac.id, ${ }^{4)}$ nur.fitriyyah@binus.ac.id, ${ }^{5)}$ liany.saputri@binus.ac.id
}

Article history:

Received 2 September 2019

Revised 9 October 2019

Accepted 15 October 2019

Available online 28 October 2019

\section{Keywords:}

Executive Information System,

Financial Service Authority,

Financial Service Industry, Hybrid

Mobile Application, Unified

Modelling Language, Unified

Process

\section{Abstract}

Background: Given the digital transformation in currently emerging digital era in Financial Service Industry; marked by the rise of Fintech; Financial Service Authority (FSA) is challenged to mitigate new type of risks that are introduced by it. As first step, Indonesia FSA seeks for an effective and efficient way to present up-to-date Strategic Information to its Top Executive Leaders to enable informed strategic decision making.

Objective: This study aimed to find the solution to provide information strategic information to Indonesia FSA executives at any-time any-where. The researchers hypothesize that mobile Executive Information System could effectively serve the purpose.

Methods: The research activities are laid out based on the Unified Process (UP) Methodology and use Unified Modelling Language (UML) diagrams to communicate the design. At the end of the study, a survey-based on TAM2 is conducted to confirm the study result. The survey is tested to measure its validity, reliability and correlation analysis using SPSS.

Results: The study produce mobile executive information system (m-EIS) geared with the latest UI technology framework; Quasar; and microservice pattern. The m-EIS is deployed and implemented. The survey result shows the overall users' acceptance of the implementation.

Conclusion: The study recommends the further enhancement of $\mathrm{m}$-EIS and highlights limitation of the current study for which future study could address and improve.

\section{INTRODUCTION}

Currently, we are living in information era [1], where data and information has strategic value and roles. By leveraging on data and information, organizations will be able to obtain valuable insight; that is generated by analyzing data and drawing conclusions [2]; to innovate and develop unique competitive advantage. It's so valuable as such that it was crowned as a the new oil, but without "finite" characteristics [3]. Along with more intense and strategic use of data, business organizations are currently undergoing digital business transformation where technology is leveraged to solve business problems, improve operational effectiveness and efficiencies, and allow informed strategic decision making [4].

Financial Service Industry (FSI) is one of the most influenced sectors by digital transformation [5]. The term Financial Technology (Fintech) is used to described FSI companies who intensively employ digital technology to provide innovation-rich financial product and services to their customers. Traditional financial service such as loan, deposits, and other services is transformed with new superior characteristics such as faster processing time, easier to use and consume, cost-effective \& efficient, and safe.

The rise of Fintech in FSI space promotes positive economic growth [8][6] as well as introducing new type of risks. Financial Service Regulatory and Supervisory body, called Financial Service Authority (FSA) should groom the Fintech to leverage its positive impact, while at the same time mitigate the risk to prevent it from materializing[5]. The use of technology for regulatory and supervision purposes; represented by term Regulatory

\footnotetext{
${ }^{*}$ Corresponding author
} 
Technology (Regtech) and Supervisory Technology (Suptech) is strategically required to manage Fintech effectively [5].

Accordingly, in 2018, Indonesia FSA has launched its strategic plan to implement IT-Based Supervision initiatives and promote healthy contribution of Fintech through optimal regulation, licensing and supervision [6]. Towards this direction, Indonesia FSA begins its long journey by providing FSI strategic information to its top executive anytime and anywhere in timely manner in order to support strategic decision making and provision of accurate and up-to-date strategic information to FSI stakeholders.

The researchers review earlier studies and found that mobile applications could serve as an effective means to deliver information at any-time and any-where [8][9]. This study has chosen to use hybrid mobile application approach based on the consideration on current HTML, CSS and Javascript skills. Earlier study also concluded that hybrid approach is an effective and efficient approach to quickly develop and deliver user-friendly mobile application [10][11]. Another study also concluded that to promote its continuous use, any EIS application should be primarily emphasize on ease-of-use and perceived of usefulness aspects [12]. As its novelty, the study introduces the use of on modern multi-platform UI Framework called Quasar Framework to develop and implement mobile application for delivering strategic information as Executive Information System (EIS) based. It enables the development of mobile EIS based on hybrid approach, and open possibility to deploy the same mobile application program to other platform such as web and desktop [13]. The Quasar Framework served as main UI Framework to develop mobile EIS.

This research aimed to answer the following research question: "Is mobile EIS could effectively present strategic information for Indonesia FSA top executive anytime and anywhere?". The purpose of this study is to analyze, design, build and implement a technological solution to answer the research the question.

\section{RELATED WORKS}

\section{A. Executive Information System}

Executive Information System (EIS) is a system that provides support to senior executives of company or organization in decision making process [12][14][15]. The concept is introduced in 1980, with capabilities to analyze trends, perform drilldown to understand root cause of problems, presenting the overall status, shows critical success indicator and predict and forecast future condition.

EIS provides internal and external strategic information that is related to strategic objectives of particular organization. EIS also used to help senior management to perform analysis, comparisons, and identification of any particular trend within organization for performance monitoring and easy identification of problem [15].

\section{B. Hybrid Mobile Application}

Hybrid Mobile Application is mobile application that is consisted of HTML pages, javascript and CSS and browser; that is part of native mobile application [16]. With this approach, the same mobile application program can be deployed and ran on different mobile operating system, including Android and iOS. It will also promote easier and faster development time.

\section{Financial Service Industry}

Financial Service Industry (FSI) is business category where comprises of companies that provide economic services with related to the management of money, including union, banking, credit card companies, insurance, accountant, consumer credit, stock broker, investment manager, investment advisor and many others [17].

\section{Financial Service Authority}

Financial Service Authority (FSA) is FSI Regulatory and Supervision Body [18]. It is a quasi-judicial; where it can interpret, constitute and issue an FSI related law; although it is not a judicial body [19]. FSA also supervised the entire aspect of FSI regulations implementations that are issued.

In Indonesia's context, FSA is an independent agency that reports directly to the President by Indonesia's Law No. 21 of 2011. Indonesia FSA was given the authority to regulate, supervise, examine, investigate FSI related infringements, as well as to educate \& protect the interest of FSI consumers. Indonesia FSA was formed to:(1) ensure ordered, fair, transparent, and accountable conduct of FSI; (2) promote growing and stable financial system; (3) protect and educate consumers and entire FSI stakeholders [20].

\section{E. Quasar Framework}

Quasar Framework is an open source UI development framework that is built by MIT that enabled web programmer with existing HTML, javascript and CSS skills to build and deploy their application to multiple device 
platforms: i) web; ii) mobile; and iii) desktop [13]. In the web environment, Quasar framework supports: i) Single Page Application (SPA); ii) Server Side Renderer (SSR); and iii) Progressive Web Application (PWA) deployment mode by leverage on a single sets of code. While same program can also be deployed to: iv) mobile environment on hybrid approach using Apache Cordova; and to v) desktop environment using Electron approach. The Quasar framework is written based on VueJS UI Framework, the work of Evan You (2014) [13][21].

\section{F. Microservice}

Microservice is software development technique and pattern; a further development of Service Oriented Architecture (SOA) that structured the application and business logic as collection of lightweight loosely-coupled and interoperate-able services that are group based on its unique functions and capability [22]. By adopting this pattern, the development, testing and capacity scaling of the services could be independently carried out without major disturbance on production system [23] [24]. It allows continuous and uninterrupted application development and operations [25].

\section{METHODS}

This study refers its activity to Unified Process (UP), an iterative and incremental software development process that adopt adaptive SDLC approach and constructed based on Agile Development Philosophy; which put the highest value on team interactions, working software, collaboration with the customer and responding to change [26].

UP comprises of defined sequential phases which are: i) inception, the initiation, and planning of the project that clarify objectives, scope and high-level business requirement in early-stage; ii) Elaboration, the identification of detail business requirement; iii) construction; the detail design and development of the software; and iv) transition, which covers the software testing and implementation.

But having said so, the phases are more ideal to be perceived as a group of activities with certain major goals rather than sequential steps because of its iterative nature. Thus, the development process is being done iteratively through-out all phase and heavily use the prototype approach to clarify business requirement with business users [26]. The Fig. 1 shows the process steps that are carried out and methods that are used in this study.

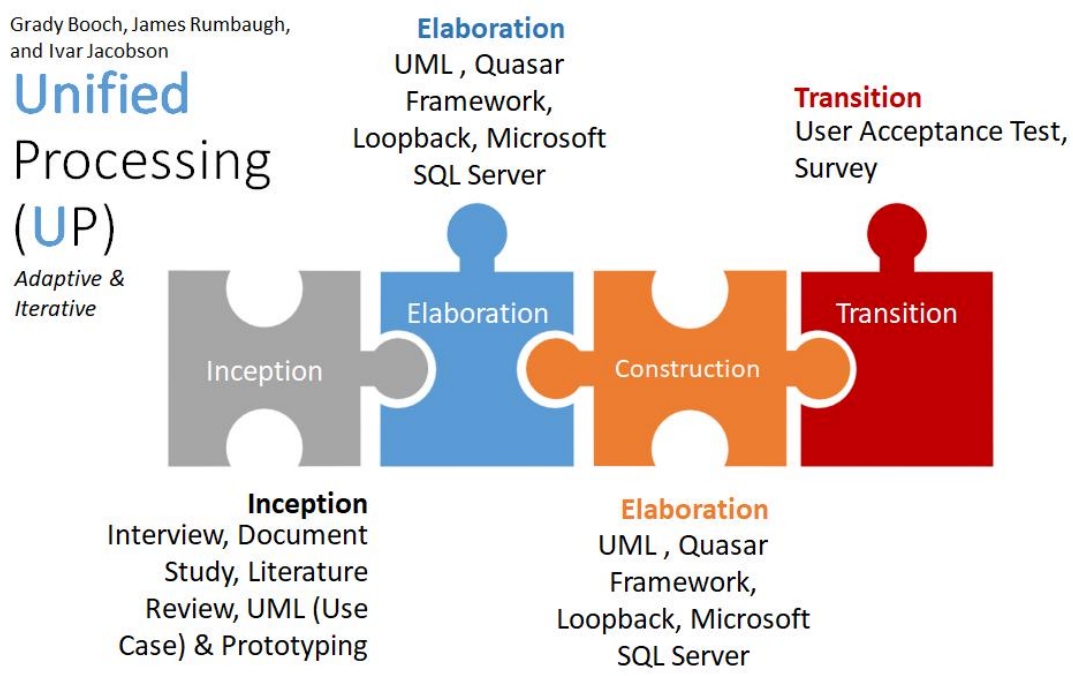

Fig. 1. Process Steps and Methods Used [26]

\section{A. Inception}

The inception phase uses the following methods to achieve its goal:

1) Interview

In this phase, the researchers perform an initial interview using questionnaires to Indonesia FSA key users, consisted of 6 open-ended questions. The interviews provide the vision, expectation, high-level business requirements and scope of the study. 


\section{2) Document Study}

The interviewee provides related documents and information to support and further elaborate the provided answer. The researchers study the provided documents and information as the basis for the initial analysis.

3) Literature Review

The review reveals that mobile-based application can be effectively used to provide information anytime and anywhere, disregard the location boundaries [8]. It also can be used to present critical information to senior managers, or even used as a dashboard [9].

With regards to the development options, the hybrid mobile application offers several benefits including: i) ability to leverage on current web programming skills; ii) multiple deployment options, which is to Android and iOS; ii) faster development time; and iv) ease of development and enhancement [10]; without sacrificing functionalities and end user experience [10]. The executive information system should also meet the user's expectation and perception criteria of usefulness and ease of use to ensure its continuous use [12].

4) $U M L$

Based on the initial analysis of interview result, document study and literature review, the study performs initial identification of requirements and draft initial solution recommendation.

To communicate the initial solution recommendation, the researches draw Use Case Diagram based on Unified Modelling Language (UML); which is modelling language that is defined by Object Management Group (OMG) to provide standard of terms, diagram notation and techniques that is used to model the information system requirement and design throughout the software development phases [26]. UML is developed mainly based on object-oriented programming (OOP).

\section{5) Prototyping}

In conjunction with use case diagram, this study also developed hybrid mobile executive information system prototype to quickly communicate the concept of the proposed solution to the key users. Based on inputs from key users, researchers revise and finalize the first prototypes as the basis for the development of the end solution. The prototype developed using the following technologies: i) Quasar as UI Framework; ii) Loopback as back end that are based on microservice pattern [27]; and iii) Microsoft SQL Server as database engine.

\section{B. Elaboration}

In this phase, the requirement is further elaborated and analyze in detail. Aside from Use Case Diagram, to communicate the understanding, the researches use more UML design diagrams such as i) domain model class diagram; ii) Use Case Description; iii) Activity Diagram and iv) System Sequence Diagram (SSD). The mobile executive information system prototype is also heavily developed and used to introduce and visualize the concept of proposed solution to address the critical requirement to the key users.

\section{Construction}

In construction phase, the mobile executive information system is developed based on approved prototypes resulted from previous phase. In the proses, minor change and additional requirement is also accommodated to complete the end product.

\section{Transition}

1) User Acceptance Test

In the last phase, researches perform user acceptance test (UAT) to confirm the readiness of the developed solution [26]. After UAT is completed, installation of related hardware and software is carried out to support the implementation of mobile executive information system.

2) Surveys

The researches distribute Likert scale based surveys to collect data to get users' feedback of implementation results. The surveys are done with the entire population of users (18 users), guided by technical acceptance model 2 (TAM2) [28]. The survey questions cover the following variables: i) perceived usefulness (job relevance, output quality, result demonstrability); ii) perceived ease of use, and iii) intention to use. The questionnaires result is later measured using validity test [29], reliability test [30] and correlation analysis [31]. The survey's question listed in Table 1. 
TABLE 1

SURVEY VARIABLE AND SUB VARIABLE

\begin{tabular}{lll}
\hline \hline No & \multicolumn{1}{c}{ Variables } & \multicolumn{1}{c}{ Sub Variable } \\
\hline 1. & Perceived Usefullness & PU1: Job relevance of the proposed solution \\
& & PU2: Completeness of Features \\
& PU3: Completeness Type of Information \\
& PU4: Bugs / Application Stability \\
& PU5: Application Performance \\
& PU6: Performance over limited Network connectivity \\
& PE1: UI Design \\
2. Perceived Ease of Use & PE2: Easy to learn \\
& & PE3: Easy to operate \\
& & IU1: Willingness to Use Continuously \\
3. & Intention to Use & IU2: Support To Future Enhancement \\
\end{tabular}

\section{RESUlts}

The study produces the following key results:

\section{A. Process Business Adjustment}

With regards to the implementation of mobile executive information systems, the study proposed the change of the following business process: i) Eliminated the needs to prepare the FSI strategic information manually to any earlier available format; ii) only access the FSI information through the mobile executive information system for inhouse and outdoor used; iii) Use mobile executive information system as web application to support the top executive general meeting. The implementation of the proposed business process change is carried out gradually based on organization readiness.

\section{B. Design Documents}

The study document mobile executive information design that are consisted of the following key information:

1) List of Key Requirements

TABLE 2

KEY REQUIREMENTS

\begin{tabular}{|c|c|c|}
\hline - & & \\
\hline No & Key Requirements & $\frac{\text { Description }}{t \text { are integrated } i}$ \\
\hline 1. & Login Screen & $\begin{array}{l}\text { Login screen that are integrated into Active Directory } \\
\text { (AD). Simplify user password management. } \\
\text { Sleek and intuitive visualization of strategic }\end{array}$ \\
\hline 2. & Chart and Graphics & $\begin{array}{l}\text { Information to ease the comprehension by top executive } \\
\text { users }\end{array}$ \\
\hline 3. & Geomap & Geospatial based visualization of strategic Information \\
\hline 4. & Near Real Time Update & $\begin{array}{l}\text { Near real time update for certain type of strategic } \\
\text { information }\end{array}$ \\
\hline 5. & Google Calendar & $\begin{array}{l}\text { Google Calendar like User Interface to visualize } \\
\text { schedule bound information }\end{array}$ \\
\hline 6. & PDF viewer & $\begin{array}{l}\text { Ability to view PDF document content, with zoom in } \\
\text { and zoom out capability, and on page by page basis. }\end{array}$ \\
\hline
\end{tabular}

\section{2) UML Diagrams}

More than $50 \mathrm{UML}$ diagrams are incorporated into the design document for future reference. The UML Diagrams are mainly used to communicate requirement with respective users. The use case diagram is mainly used in conjunction with the prototype during the Inception phase to depicted the high-level requirement and the project scope. The activity diagram and sequence diagram are developed during the elaboration phase to clarify the user interaction process together with its information flow. The class diagram is developed to identify the type of information that queried and presented in the UI. 


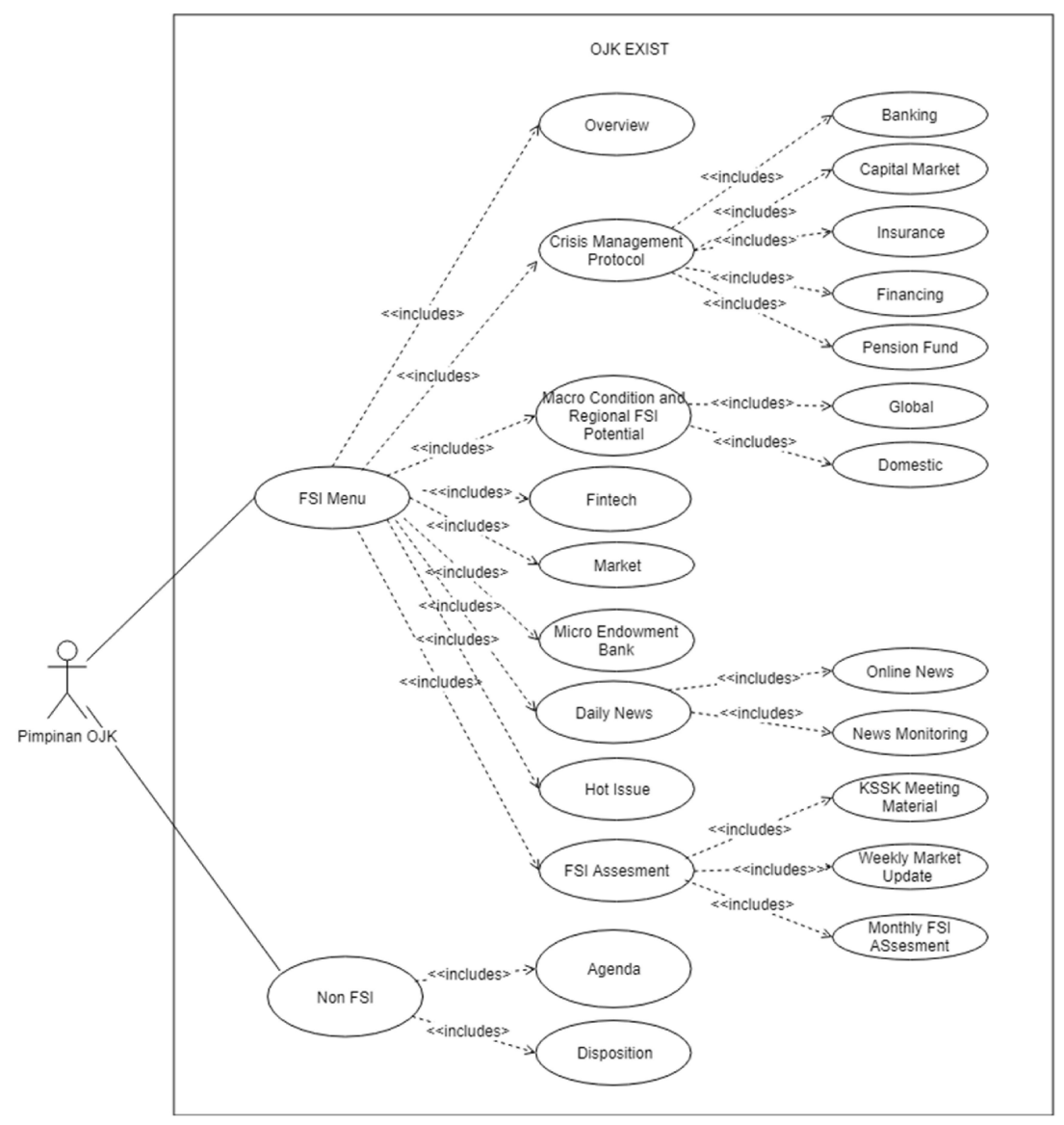

Fig. 2. Fragment of Use Case Diagram

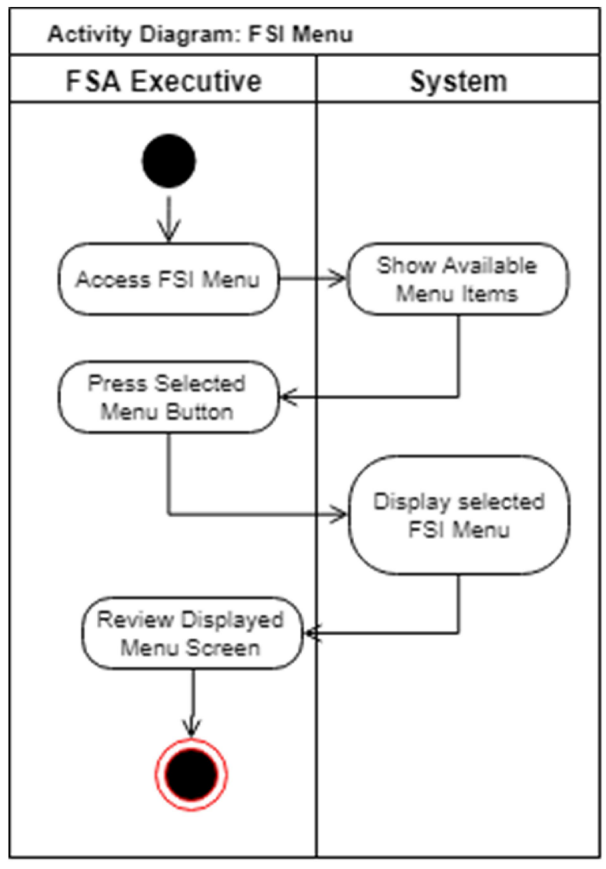

Fig. 3. Fragment of Activiy Diagram 


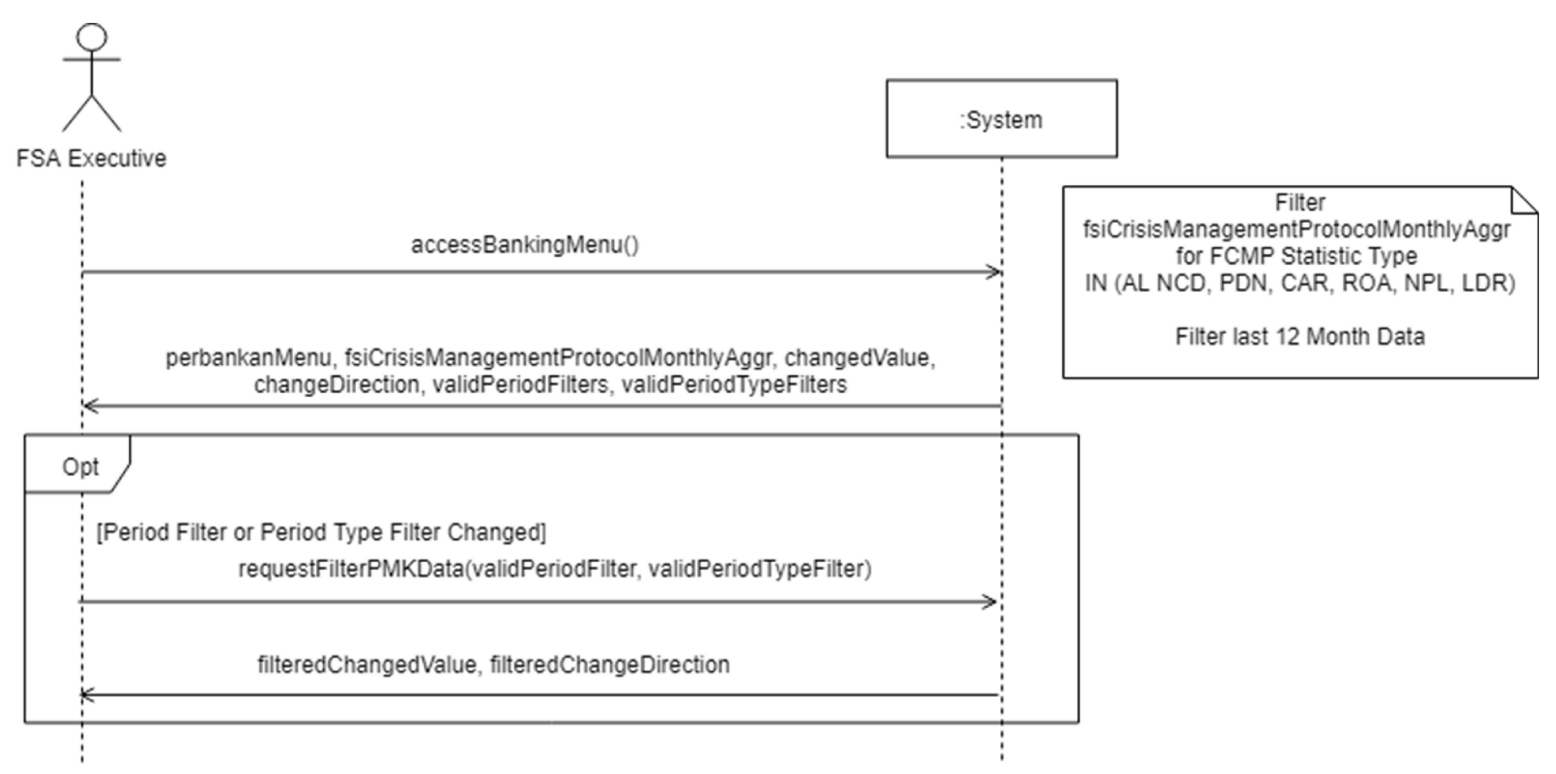

Fig. 4. Fragment of Sequence Diagram

\section{3) UI Designs}

The User Interface (UI) is designed to support the functional requirement such as graphical, Geomap, and calendar; also to allow ease of use. The UI design mainly finalized by mean of prototyping rather than formal sketch/drawing. The fragment of UI design depicted in Fig. 5.
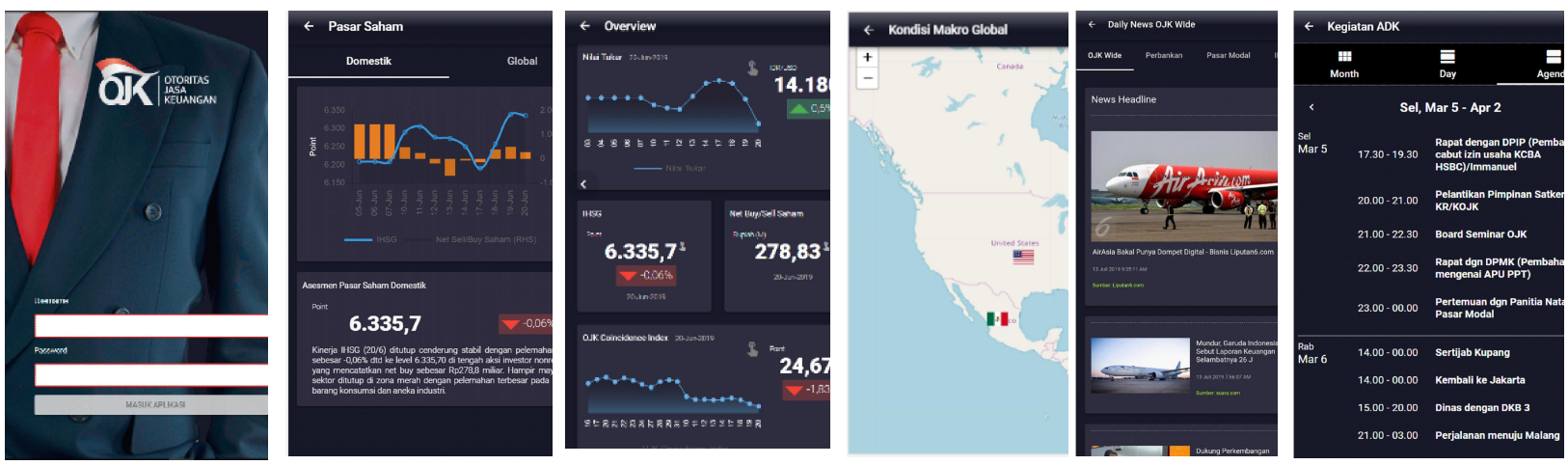

Fig. 5. Fragment of UI Designs

The UI also support interactive drilldown by double-tap on certain chart/graphic, image, icon and view. All data is queried at the first load of the screen to allow fast response during drilldown. The geomap view support zoom-in and zoom-out capability that is very similar to google map.

4) Testing Scenario and Results

The mobile executive information system is tested based on test scenario that contains: (1)Scenario ID; (2) Use case no; (3) Description; (4) Test Condition; (5) Expected Results. The test result is documented which consisted of: (1) Tester name; (2) Test Date; (3) Testing criteria; (4) Status; (5) Outstanding Issues. There are 101 testing scenarios generated and executed. The scenarios guide formal user acceptance test carried out during the transition phase. While the actual unit testing and integration are being done during the construction phase. Fragments of both Test Scenarios (Column 1 to 5) and Test Results (entire table) are shown in Table 3. 
TABLE 3

FRAGMENT OF TESTING SCENARIO AND TESTING RESULTS

\begin{tabular}{|c|c|c|c|c|c|c|c|c|c|}
\hline $\begin{array}{c}\text { ID } \\
\text { Scenario }\end{array}$ & $\begin{array}{c}\text { Use } \\
\text { Case } \\
\text { No }\end{array}$ & Description & $\begin{array}{c}\text { Testing } \\
\text { Condition }\end{array}$ & " Desired Result & $\begin{array}{l}\text { Tester } \\
\text { Name }\end{array}$ & Testing Date & $\begin{array}{l}\text { Testing } \\
\text { Criteria }\end{array}$ & Status & $\begin{array}{c}\text { Outstanding } \\
\text { Issues }\end{array}$ \\
\hline 00 & A. 0 & Login & $\begin{array}{l}\text { Login for } \\
\text { the first } \\
\text { time }\end{array}$ & $\begin{array}{l}\text { Login screen appeared } \\
\text { User can input } \\
\text { username and } \\
\text { password } \\
\text { False username and } \\
\text { password is rejected } \\
\text { Correct username and } \\
\text { password is accepted } \\
\text { After first successful } \\
\text { login, user can access } \\
\text { application without } \\
\text { login }\end{array}$ & IR & 20-Jun-2019 & $\begin{array}{l}\text { Login using } \\
\text { LDAP Login } \\
\text { ID }\end{array}$ & Accepted & None \\
\hline
\end{tabular}

\section{5) Hardware and Software Component}

The mobile executive information system is developed using software and operated using hardware with the specification as per stated in Table 4, and Table 5. The interaction of each software component is depicted in Fig. 6.

TABLE 4

SOFTWARE SPECIFICATION

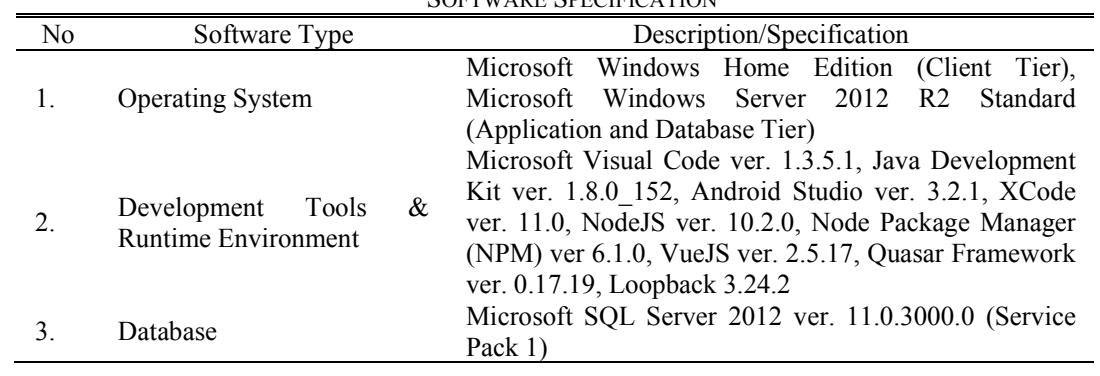

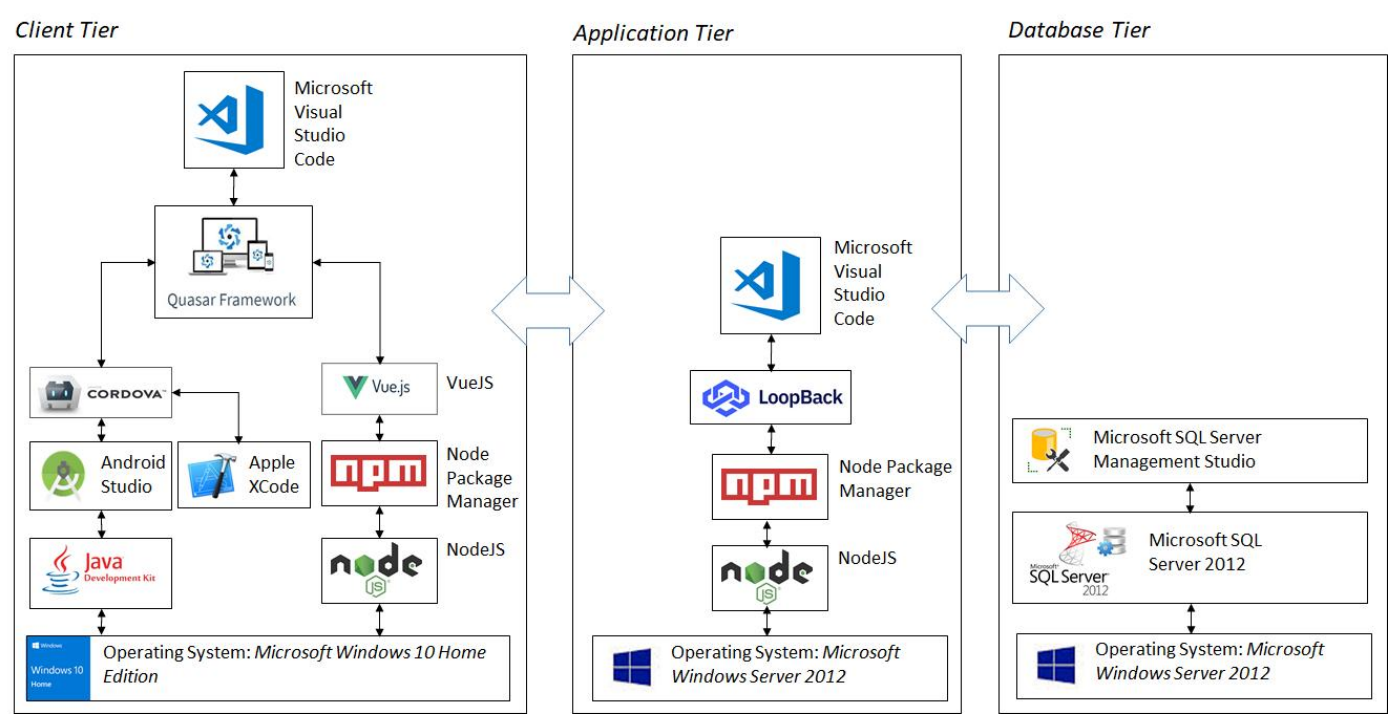

Fig. 6. Software used to develop the solution 
The Fig. 6 depicted that the software used in this study are categorized into 3 tiers, which are: Client Tier, Application Tier, and Database Tier.

On the client tier, which represents the mobile application, the researchers used Visual Code as Integrated Development Environment (IDE) ran under Microsoft Windows 10 Home Edition to write and organized a mobile EIS program based on Quasar Framework. The Quasar Framework used Apache Cordova to deploy the program to Android OS via Android Studio Tools. The Apache Cordova also allows the deployment of the software to iOS via Apple XCode Software. The Quasar Framework itself was made on top of the VueJS Framework and was administer through node package manager software that was running on top of the NodeJS runtime environment. While on the application tier, the study also used Visual Code as IDE ran under Microsoft Windows Server 2012, with Loopback as an application logic framework that administered through node package manager software that was running on top of NodeJS runtime environment. At last, on the database tier, the study used Microsoft SQL Server 2012 that ran under Microsoft Windows Server 2012 operating system.

TABLE 5

HARDWARE SPECIFICATION

\begin{tabular}{lll}
\hline \hline No & \multicolumn{1}{c}{ Software Type } & \multicolumn{1}{c}{ Description/Specification } \\
\hline \multirow{3}{*}{ 1. } & \multirow{3}{*}{ Application Server } & Intel(R) Xeon(R) Gold 6138 CPU @ 2.00GHz, 1995 \\
& & Mhz, 2 Core(s), 2 Logical Processor(s), Memory 4 GB, \\
& 100 GB Harddisk, dalam Virtual Machine HyperV \\
2. Database Server & Intel(R) Xeon(R) Gold 6138 CPU @ 2.00GHz, 1995 \\
& & Mhz, 2 Core(s), 2 Logical Processor(s), Memory 4 GB, \\
& 250 GB Harddisk \\
\hline
\end{tabular}

\section{Mobile Executive Information System}

The mobile executive information system (m-EIS) is developed with the capability to present updated FSI strategic information, which are local and world currencies' s exchange rate, security indexes, inter-bank money market, FSI companies's health ratio, crisis management protocol, worlds and domestic macroeconomics, Fintech industry development, endowment micro banks - based on sharia principles, surveillance assessment, daily online news, FSI related hot issues, including the resolution progress.

The period of update of strategic information varies from one type to another; ranging from near-real-time to monthly updates. In addition to that strategic information, the m-EIS also provides supporting information, which are internal and external agendas of individuals respective executive and executives work memos to the working team. The m-EIS can be operated using android and iOS smartphones, or other devices such as iPad. Access requires a minimum of HSDPA connection for smooth operation. In addition to that, the same application could be access through browsers. It gives flexibility to users to conveniently operate the m-EIS using personal devices or on office's desktop.

\section{Implementation}

The mobile executive information system (m-EIS) is successfully implemented and used by the Indonesia FSA executive users. The m-EIS is able to provide executive users with FSI Strategic and supporting Information at anytime and any-where; using personal android and iOS based smartphones or other types of mobile devices such as $\mathrm{iPad}$. The study has delivered all required functional and non-functional requirement.

\section{E. Survey Test Result}

The survey measurement result of validity, reliability, and correlation all variable that is represented in the survey is depicted in Table 6-8.

TABLE 6

\begin{tabular}{|c|c|c|c|c|c|c|c|c|c|c|c|c|}
\hline & PU1 & PU2 & PU3 & PU4 & PU5 & PU6 & PE1 & PE2 & PE3 & IU1 & IU2 & Total \\
\hline Pearson Correlation & .525 & .728 & .764 & .789 & .679 & .660 & .646 & .667 & .671 & .519 & .796 & 1 \\
\hline Sig. (2-tailed) & .025 & .001 & .000 & .000 & .002 & .003 & .004 & .002 & .002 & .027 & .000 & \\
\hline $\mathrm{N}$ & 18 & 18 & 18 & 18 & 18 & 18 & 18 & 18 & 18 & 18 & 18 & 18 \\
\hline
\end{tabular}


TABLE 7

RELIABILITY TEST RESULT

\begin{tabular}{lr}
\hline \hline Cronbach's Alpha & N of Items \\
\hline .882 & 18
\end{tabular}

TABLE 8

CORRELATIONS TEST RESULT

\begin{tabular}{rlrrr}
\multicolumn{5}{c}{ CORRELATIONS TEST RESULT } \\
\hline \hline PU & PU & PE & IU \\
& Pearson Correlation & 1 & .782 & .784 \\
& Sig. (2-tailed) & & .000 & .000 \\
& N & 18 & 18 & 18 \\
& & & & \\
PE & Pearson Correlation & .782 & 1 & .607 \\
& Sig. (2-tailed) & .000 & & .008 \\
& N & 18 & 18 & 18 \\
& Pearson Correlation & .784 & .607 & 1 \\
& Sig. (2-tailed) & .000 & .008 & \\
& N & 18 & 18 & 18 \\
\hline
\end{tabular}

Given the $r$ table value of population - 2 or 16 equals to 0.4683 , and alpha value of 0.05 , the survey measurement results are interpreted as follow:

1) Validity

All variable and sub variable are valid, based on the observation of total score of each sub variable (Table 6.) are greater than $r$ table value; which is 0.4683 [29].

2) Reliability

All variable and sub variable are reliable, based on the observation of Cronbach's Alpha value (Table 7.); which is 0.882 is greater than 0.6 [30].

3) Correlation

Variable PU (Perceived Usefulness) is significantly correlated with variable IU (Intention to Use), based on the observation that pearson correlation score; which is 0.784 is greater than $r$ table value; which is 0.4683 . As alternative observation: Sig. (2-tailed) correlation score value of variable PU over IU; which is 0.000 is less than 0.05 as alpha value.

Variable PE (Perceived Ease of Use) is significantly correlated with variable IU (Intention to Use), based on the observation that pearson correlation score; which is 0.607 is greater than $r$ table value; which is 0.4683 . As alternative observation: Sig. (2-tailed) correlation score value of variable PU over IU; which is 0.008 is less than 0.05 as alpha value [31]

TABLE 9

HARDWARE SPECIFICATION

\begin{tabular}{|c|c|c|c|c|}
\hline No & $\begin{array}{l}\text { Software } \\
\text { Type }\end{array}$ & Description/Specification & $\begin{array}{c}\text { Average } \\
\text { Result }\end{array}$ & $\begin{array}{c}\text { Acceptance } \\
\text { Rate }\end{array}$ \\
\hline \multirow{12}{*}{1.} & Perceived & PU1: Job relevance of the proposed solution & \multirow{2}{*}{4.1} & \multirow{2}{*}{$82 \%$} \\
\hline & Usefullness & Question: The m-EIS is relevance to my duties and responsibilities & & \\
\hline & & PU2: Completeness of Features & \multirow{2}{*}{4.4} & \multirow{2}{*}{$88 \%$} \\
\hline & & Question: The m-EIS's feature is complete and already met my current needs & & \\
\hline & & PU3: Completeness Type of Information & \multirow{2}{*}{4.0} & \multirow{2}{*}{$81 \%$} \\
\hline & & Question: The m-EIS has fulfilled all the strategic information requirement & & \\
\hline & & PU4: Bugs / Application Stability & \multirow{2}{*}{4.2} & \multirow{2}{*}{$84 \%$} \\
\hline & & Question: The m-EIS can be operated without any major problems/bugs & & \\
\hline & & PU5: Application Performance & \multirow{2}{*}{4.3} & \multirow{2}{*}{$87 \%$} \\
\hline & & Question: The m-EIS's performance is adequate to allow me to use it with ease and comfort & & \\
\hline & & PU6: Performance over limited Network connectivity & 44 & \multirow{2}{*}{$88 \%$} \\
\hline & & Question: The m-EIS can be operated without problem in limited network connectivity & \multirow{3}{*}{4,2} & \\
\hline \multirow{6}{*}{2.} & Perceived & PE1: UI Design & & $84 \%$ \\
\hline & Ease of Use & Question: The m-EIS's UI design is simple and aesthetic & & \multirow{3}{*}{$86 \%$} \\
\hline & & PE2: Easy to learn & \multirow[t]{2}{*}{4.3} & \\
\hline & & Question: The m-EIS is easy to be learnt without attended help & & \\
\hline & & PE3: Easy to operate & \multirow[t]{2}{*}{4.2} & \multirow[t]{2}{*}{$84 \%$} \\
\hline & & Question: The m-EIS is easy to operate without significant help & & \\
\hline \multirow{4}{*}{3.} & Intention to & IU1: Willingness to Use Continuously & \multirow[t]{2}{*}{4.2} & \multirow[t]{2}{*}{$84 \%$} \\
\hline & Use & Question: I will continuously use m-EIS to support my daily works. & & \\
\hline & & IU2: Support To Future Enhancement & \multirow[t]{2}{*}{4.4} & \multirow[t]{2}{*}{$88 \%$} \\
\hline & & Question: I support the m-EIS to be further developed and enhanced. & & \\
\hline
\end{tabular}


The result of statistical validity and reliability test shown that all the survey answers are valid and reliable to be used a reference to quantitatively measure the result of mobile EIS implementation that are represented by survey questions. The correlation analysis also indicated that positive perception on ease of use and usefulness will increase the user's intention to use the developed solution. The survey result is summarized in Table 9.

\section{DISCUSSION}

Supported by the Quasar Framework, the mobile EIS was able to effectively deliver all key requirements as per stated in Table 2 that are requested by the users to present Strategic FSI (including the Fintech Industry) Information; to FSA's Top Executive. The UI of mobile EIS also rich in terms of feature and variety, to accommodate different requirements of visualization and presentation. Quasar Framework has demonstrated its value by simplifying the development process despite the underlying sophisticated and complex technology stack as depicted in Fig 5.

Based on the result of survey as per described in Table 9, the users perceived that m-EIS is relevant to their duties and responsibilities (Table 9. Question PU1). The users also perceived the developed mobile EIS as preferred reference for FSI Strategic Information based on its completeness of features and information (Table 9. Question PU2 \& PU3).

The mobile EIS also allows the executive to have an up-to-date strategic and supporting information; which enable them to make an informed strategic decision any-time and any-where (Table 9. Question PU5 \& PU6). The users can learn and use m-EIS with ease and comfort; as it's considered to have an intuitive, sleek, simple, and aesthetic design (Table 5 Question PE1, PE2 and PE3). The m-EIS is operated with minimum bugs and demonstrate adequate performance given the mobile network connectivity variation and limitation that may occur (Table 9. Question PU4, PU5 and PU6). The users express their willingness to continuously use m-EIS (Table 9. Question IU1) and support its the future development and enhancement that could extend its usage and potentially bring more benefit (Table 9. Question IU2). The user satisfied by the result of the study and reflected it in the survey's answer with the approval rate for more than 80 percent. The result also indicate that the study has successfully implemented UP methodology to capture business requirement using UML technique and prototyping, and accurately develop, test and deliver the mobile EIS end product that meet user 's requirement and expectation.

The result of this study supports the earlier study's conclusion that the user's intention to continuously use BI Systems such as EIS is mainly influenced by perceived ease of use and usefulness [12]. The study use hybrid mobile application approach similar to the earlier study and use a new modern Framework [10]. But none of the earlier mobile application has the capability to be deployed as Web and Desktop application [8][9]. The study also is the first which introduced the use of the mobile EIS for FSA, delivering FSI Strategic Information to top executives.

The scope of the study is limited to the presentation aspect of the requirement, and the near-real-time data capture capabilities. While data preparation arrangement is separately catered by internal business and IT team. In addition to that, the post-implementation survey used 3 TAM variables and some of its sub-variables. This approach is used mainly because the survey itself is not the main activity of the research, but rather as a complement to UP as a primary methodology. In addition to that, earlier study pointed out that the ease of use and perceived of usefulness are the main factors that influence the user's intention to continuously use Business Intelligence Application [12].

\section{CONCLUSIONS}

Based on the study result and survey's answers provided by users at the end of the study, the study concluded that mobile EIS is effective to serve the purpose of presenting strategic information as needed by top executive; at anytime any-where. The study recommends various features and capabilities that could be incorporated as part of future development and enhancement of m-EIS. Administrative function to manage users, roles, menus, and access rights will allow admin users to customized menus structure for particular group of users, based on their specific interest and needs. To further extend its usage, new types of information could be added. Also, the provision of additional supporting drill-down information of each strategic information will be beneficial for the executive users to obtain the next level of comprehension on FSI strategic conditions. Predictive and prescriptive analytical capabilities will potentially provide advanced support for decision making process. 
It is also possible to optimize the utilization of Quasar Framework; as UI Framework, by deploying it as a desktop application. This way, the developed solution can be also being used to provide operational information to managerial and tactical users. It will standardize the approach and serves as single reference for information provision for decision making purposes at any level of organization. The m-EIS is potentially to be used as a channel for online communication and collaboration between the executive and its managerial team. The directive from leaders and assessment report from the tactical team on particular strategic information could be exchanged via this channel. Future addition of over-the-air (OTA) application update features also important to allow continuous, safe and comfort use of m-EIS.

\section{REFERENCES}

[1] M. Castells, \& C. Blackwell, The information age: economy, society and culture. Volume 1. The rise of the network society. Environment and Planning B: Planning and Design, 25, 631-636, 1998.

[2] B. Dykes, "Actionable Insights: The Missing Link Between Data And Business Value," Forbes, 08-Aug-2016. [Online]. Available: https://www.forbes.com/sites/brentdykes/2016/04/26/actionable-insights-the-missing-link-between-data-and-businessvalue/\#360c27cd51e5. [Accessed: 20-Aug-2019].

[3] B. Marr, "Here's Why Data Is Not The New Oil," Forbes, 05-Mar-2018. [Online]. Available: https://www.forbes.com/sites/bernardmarr /2018/03/05/heres-why-data-is-not-the-new-oil/\#54141b383aa9. [Accessed: 20-Aug-2019].

[4] Matt, C., Hess, T., \& Benlian, A. (2015). Digital transformation strategies. Business \& Information Systems Engineering, 57(5), 339-343.

[5] Toronto Centre, Fintech, RegTech and SupTech: What They Mean for Financial Supervision, 2017, [Online], Available: https://res.torontocentre.org [Accessed August 20 2019].

[6] Otoritas Jasa Keuangan, Infografis Perkembangan Sektor Jasa Keuangan dan Kinerja OJK 2018, [Online], Available: https://www.ojk.go.id/id/berita-dan-kegiatan/info-terkini/Pages/Infografis-Perkembangan-Sektor-Jasa-Keuangan-dan-Kinerja-OJK2018.aspx, [Accessed: 20-Aug-2019].

[7] A. Riyanto, I. Primiana, \& Y. Azis, Y. Disruptive Technology: The Phenomenon of FinTech towards Conventional Banking in Indonesia. In IOP Conference Series: Materials Science and Engineering (Vol. 407, No. 1, p. 012104). IOP Publishing, 2018

[8] T. Schlachter, C. Düpmeier, R. Weidemann, W. Schillinger \& N. Bayer, "My Environment"-A Dashboard for Environmental Information on Mobile Devices. In International Symposium on Environmental Software Systems (pp. 196-203). Springer, Berlin, Heidelberg, 2013.

[9] C. Gröger, C. Stach, B. Mitschang, \& E. Westkämper, A mobile dashboard for analytics-based information provisioning on the shop floor. International Journal of Computer Integrated Manufacturing, 29(12), 1335-1354, 2016.

[10] R. Mahato, Hybrid Mobile Application Development, 2016.

[11] L. Andersson, L. Usability and User Experiencein Mobile App Frameworks: Subjective, but not Objective, Differences between a Hybrid and a Native Mobile Application, 2018

[12] S. Bischoff, S. Aier, M. K. Haki, \& R. Winter, Understanding continuous use of business intelligence systems: A mixed methods investigation. JITTA: Journal of Information Technology Theory and Application, 16(2), 5. 2015.

[13] MIT, Introduction to the Quasar Framework. 2016, [Online]. Available: https://quasar-framework.org/guide/introduction-to-quasar.html, [Accessed: 20-Aug-2019].

[14] R. Sharda, D. Delen, E. Turban, J. E. Aronson, T. Liang, D. King, E. Turban, Business intelligence and analytics: Systems for decision support. Boston: Pearson, 2014.

[15] D. J. Power, Decision support systems: concepts and resources for managers. Greenwood Publishing Group., 2002

[16] K. A. More, \& M. P. Chandran, Native Vs Hybrid Apps. Proceeding of International Journal of Current Trends in Engineering \& Research, 563-572., 2016.

[17] Asmundson, I. Financial Services: Getting the Goods. 2018. . [Online], Available: https://www.imf.org/external/pubs/ft/fandd/ basics/finserv.htm, [Accessed: 20-Aug-2019].

[18] Ferran, E., 2014. The break-up of the Financial Services Authority in the UK. In Institutional Structure of Financial Regulation (pp. $127-$ 154). Routledge.

[19] M. Ojo, The Financial Services Authority: A Model of Improved Accountability? The Financial Services Authority: A Model of Improved Accountability? 2011.

[20] "Law Of The Republic Of Indonesia Number 21 Year 2011" [Online]. Available: http://www.ojk.go.id/en/regulasi/otoritas-jasakeuangan/undang-undang/Documents/Pages/law-no-21-of-year-2011-on-financial-services-authority/Full Version-Unofficial Translation of The FSA Law.pdf. [Accessed: 20-Aug-2019].

[21] E. You, Introduction - Vue.js., E. 2014 [Online]. Available: https://vuejs.org/v2/guide/, [Accessed: 20-Aug-2019].

[22] L. Chen, Microservices: architecting for continuous delivery and DevOps. In 2018 IEEE International Conference on Software Architecture (ICSA) (pp. 39-397). IEEE. 2018.

[23] L. Chen \& M. A. Babar, Towards an evidence-based understanding of emergence of architecture through continuous refactoring in agile software development. In 2014 IEEE/IFIP Conference on Software Architecture (pp. 195-204). IEEE., 2014

[24] C. Richardson, Pattern: microservice architecture. URL: http://microservices. io/patterns/microservices. html. 2017.

[25] A. Balalaie, A. Heydarnoori, \& P. Jamshidi, Microservices architecture enables devops: Migration to a cloud-native architecture. IEEE Software, 33(3), 42-52. 2016.

[26] J. W. Satzinger, R. B. Jackson, \& S. D. Burd, Systems analysis and design in a changing world. Boston, MA: Cengage Learning., S. D. 2016 
[27] Strong Loop, IBM, “LoopBack 4: Build Amazing APIs,” LoopBack, 2019. [Online]. Available: https://loopback.io/. [Accessed: 21-Aug2019].

[28] V. Venkatesh, \& F. D. Davis, A theoretical extension of the technology acceptance model: Four longitudinal field studies. Management science, 46(2), 186-204. 2000.

[29] Y. N. Sufren, Mahir menggunakan SPSS secara otodidak. Elex Media Komputindo., 2013

[30] A. Juliandi, S. Manurung, \& B. Satriawan, Mengolah Data Penelitian Bisnis Dengan SPSS. Lembaga Penelitian dan Penulisan Ilmiah AQLI., 2018

[31] R. A. Purnomo, Analisis Statistik Ekonomi dan Bisnis Dengan SPSS. CV. WADE GROUP bekerjasama dengan UNMUH Ponorogo Press., 2016 